\title{
Cuttings of post fire epicormic shoots of Ilex paraguariensis and Cabralea canjerana adult plants
}

\author{
Dilson Antônio Bisognin ${ }^{1 *}$ Kelen Haygert Lencina ${ }^{2}$ Paula Kielse $^{1}$ Frederico Dimas Fleig $^{3}$ \\ Ronilda Silveira ${ }^{2}$ Eliseo Salvatierra Gimenes ${ }^{4}$
}

'Departamento de Fitotecnia, Centro de Ciências Rurais (CCR), Universidade Federal de Santa Maria (UFSM), 97105-900, Santa Maria, RS, Brasil. E-mail: dilson.bisognin@ufsm.br. "Corresponding author.

${ }^{2}$ Programa de Pós-graduação em Engenharia Florestal, Centro de Ciências Rurais (CCR), Universidade Federal de Santa Maria (UFSM), Santa Maria, RS, Brasil. ${ }^{3}$ Departamento de Ciências Florestais, Centro de Ciências Rurais (CCR), Universidade Federal de Santa Maria (UFSM), Santa Maria, RS, Brasil. ${ }^{4}$ Instituto Federal de Ciência e Tecnologia Farroupilha (IFFar), Santa Maria, RS, Brasil.

ABSTRACT: The aim of this research was to evaluate the feasibility of rescuing adult plants by cuttings from post-fire epicormic shoots. We evaluated the native tree species erva mate (Ilex paraguariensis St. Hil.) and canjerana (Cabralea canjerana Vell. Mart.), which present difficult seedling production and are economically and ecologically important. The plant material used for the preparation of cuttings consisted of shoots from bud differentiation of tissue from the stem collar of the trees. One-bud cuttings of erva mate were treated with $4000 \mathrm{or} 8000 \mathrm{mg} \mathrm{L}^{-1}$ of indolebutiric acid (IBA) and the checks were not treated with auxins. The cuttings were grown in three different substrates: carbonized rice husks, vermiculite and coarse sand. The experiment was a factorial with a completely random design and five replicates of five cuttings. One-bud cuttings from the basal, intermediate and apical parts of canjerna shoots were treated with 0 or $6000 \mathrm{mg} L^{-1}$ of IBA and planted in commercial substrate and coarse sand (3:2 v/v). The experiment was a factorial with a completely random design and ten replicates of three cuttings. Cuttings from post-fire epicormic shoots can be used for rescuing erva mate and canjerana adult plants. Erva mate cuttings treated with $8000 \mathrm{mgL}^{-1}$ IBA have increased rooting when grown in coarse sand. Canjerana cuttings from the basal part of epicormic shoots have greater survival and rooting than those from intermediate and apical parts. Key words: vegetative propagation, revigoration, indolebutiric acid, substrate, plantlet production.

\section{Resgate de árvores adultas de erva-mate e canjerana} por estaquia de brotos epicórmicos de rebrota pós-fogo

RESUMO: O objetivo deste trabalho foi avaliar a possibilidade de resgatar árvores adultas por estaquia de brotos epicórmicos de rebrota pós-fogo. Foram estudadas a erva-mate (Ilex paraguariensis St. Hil.) e a canjerana (Cabralea canjerana Vell. Mart.), que são espécies nativas de dificil propagação por sementes e de relevante importância econômica e ecológica. O material vegetativo utilizado para o preparo das estacas foi constituído de brotos, provenientes da rebrota da diferenciação dos tecidos de gemas do colo de árvores matrizes com, aproximadamente, 20 anos de idade. Para a erva-mate, estacas de gema única foram tratadas com 4000 e $8000 \mathrm{mg}^{L^{-1}}$ de ácido indolbutírico (IBA), e as testemunhas que não receberam tratamento auxínico. As estacas foram cultivadas em três diferentes substratos: casca de arroz carbonizada, vermiculita e areia de granulometria grossa. O experimento foi um fatorial no delineamento inteiramente casualizado, com cinco repetições de cinco estacas. Para canjerana, estacas basais, medianas e apicais de gema única, foram ou não tratadas com $6000 \mathrm{mg} L^{-1}$ de IBA e cultivadas em substrato comercial e areia de granulometria grossa (3:2 v/v). O experimento foi um fatorial no delineamento inteiramente casualizado, com dez repetições de três estacas. A estaquia de rebrota pós-fogo pode ser utilizada para o resgate de árvores adultas de erva-mate e canjerana. Estacas de erva-mate tratadas com 8000mg $L^{-1}$ de IBA enraizam melhor em areia grossa. Estacas de canjerana, obtidas da porção basal das brotações, apresentam maior sobrevivência e enraizamento do que as medianas e apicais. Palavras-chave: propagação vegetativa, revigoramento, ácido indolbutírico, substrato, produção de mudas.

\section{INTRODUCTION}

The seedling, seed and forest nursery sector has been growing since 1996, due to increased recovery of degraded areas, pressure from consumer countries for certified wood and forest replacement requirements (REMADE, 2007), which have led to a considerable increase in the demand for quality seedlings. The forest code also prescribes that in the case of forest replacement, priority should be given to native species of the same biome where the elimination occurred (BRASIL, 2012), but the difficulty of producing seedlings in sufficient quantities has been a limiting factor to meet the demand for ecological restoration programs (SANTARELLI, 2004).
Tree species present a high rate of crosspollination, due to their heterozygous behavior, which leads to high genetic variability between and within progenies (FERRARI et al., 2004). In this case, the propagation by seeds provides seedlings that don't have uniformity (relative to seedling height and diameter) and subject to low genetic quality, which can be detrimental to the uniformity and productivity of stands. In addition, production of seedlings is hampered in species that have low seed availability or present seeds that are dormant or recalcitrant to storage, which is the case of erva mate (Ilex paraguariensis St. Hil.) seeds, which present integumentary and embryonic dormancy and of canjerana (Cabralea canjerana Vell. Mart.), which are recalcitrant and lose viability 
after 10 days of processing (LONGHI, 1995). Erva mate has an important socio-economic role in several municipalities in southern Brazil, related to marketing of leaves and branches used for the preparation of mate and teas (WENDLING et al., 2007). Canjerana is considered one of the most valuable timbers in southern Brazil, especially because of its high durability when exposed to weather and good workability (BACKES \& IRGANG, 2009), in addition to providing byproducts for the manufacture of dyes and perfumes and serving as raw material for medicines and extracts with insecticide action (CARVALHO, 2003).

To work around seminal seedling production problems, cuttings of selected adult trees have been investigated, although without much success. This is due to the high degree of plant maturity, making adventitious root induction difficult or impossible (PIJUT et al., 2011). However, recalcitrance to rooting is a feature that may be reversible (HACKETT \& MURRAY, 1993) by the use of some strategies such as micropropagation, plant growth inhibitors, serial propagation, successive pruning and regrowth (BITENCOURT et al., 2009; WENDLING et al., 2014). Epicormic shoots from lateral buds from the base of the plant have been used for the propagation of some tree species (PIJUT et al., 2011; WENDLING et al., 2013), enabling the rescue of adult plants that present difficult rooting.

Considering the importance of seedling juvenility for increasing the rooting capacity, this study aimed to evaluate the possibility of rescuing adult erva mate and canjerana trees by cuttings from post-fire epicormic shoots.

\section{MATERIALS AND METHODS}

The experiments were carried out in the greenhouse, in the period from May to August 2010. Vegetal material consisted of post-fire epidormic shoots of 20 erva mate trees and 10 canjerana trees, about 20 years old, established in native stands in the experimental area of the UFSM campus. The fire was superficial, reaching the litter and damaging the aerial part (trunk and canopy) of individuals of all species that presented diameter at breast height less than $10 \mathrm{~cm}$. Ten months after the accidental passage of fire, which occurred in July 2009, we collected the post-fire shoots from the collar of the plants.

In one experiment, the epicormic shoots of erva mate were sectioned into cuttings with one bud, keeping a leaf cut in half. All portions of the shoots were used. The base of the cuttings was immersed in solution containing 0,4000 or $8000 \mathrm{mg} \mathrm{L}^{-1}$ indolbutyric acid (IBA), for 10 seconds, and grown in trays of 128 cells $(26.5 \mathrm{~mL}$ per cell) containing carbonized rice husk, vermiculite and coarse sand (particles between 1.0 and $3.0 \mathrm{~mm}$ ). For the preparation of the IBA solution, auxin was previously dissolved in 50\% ethyl alcohol $\left(96^{\circ} \mathrm{GL}\right)$ and diluted in $50 \%$ distilled water. The control treatment consisted only of distilled water and alcohol in a proportion of 1:1 (v/v).

The experiment was a $3 \times 3$ factorial (concentrations of IBA and substrate type) in a completely randomized design, with five replicates of five cuttings. At 90 days of growth, the number and length $(\mathrm{cm})$ of roots and the percentages of survival, rooting, callus and sprouting were evaluated.

In another experiment, epicormic shoots of canjerana were sectioned into cuttings with one bud and one leaf cut in half, which were classified with regard to position of shoot collection (basal, median and apical) and treated or not with $6000 \mathrm{mg} \mathrm{L}^{-1}$ of IBA, for 10 seconds. The cuttings were arranged in polyethylene trays $(55 \times 34 \times 15 \mathrm{~cm})$ containing commercial substrate of pine bark and coarse sand $(3: 2 \mathrm{v} / \mathrm{v})$. This type of container was chosen because of the difficulty of assessing canjerana roots formed in styrofoam trays, due to the damage caused to the roots during samples collection.

The experiment was a $3 \times 2$ factorial (cutting positions and concentration of IBA) in a completely randomized design, with ten replicates of three cuttings. At 90 days of cultivation, the percentages of survival, rooting and sprouting and the number and length of shoots and roots $(\mathrm{cm})$ were evaluated.

Cuttings were kept in a wet chamber with sprinkler irrigation system, with relative humidity at approximately $85 \%$ and an average temperature of $27^{\circ} \mathrm{C}$. The data were submitted to analysis of variance and means were compared by Tukey's test at 5\% probability. For statistical analysis, the percentage data were transformed to $\arcsin \sqrt{x / 100}$ and the count data to $\sqrt{x+0,5}$.

\section{RESULTS AND DISCUSSION}

There was significant interaction between the concentrations of IBA and the type of substrate for the percentages of rooting, survival and sprouting of erva mate cuttings (Table 1), but there was no interaction between these factors for the number and length of roots and percentage of calli (Table 2) at 90 days of cultivation, which is why the results are presented separately. Erva mate cuttings treated with $8000 \mathrm{mg} \mathrm{L}^{-1}$ of IBA and planted in sand presented a higher percentage of rooting and lower percentage of sprouting at 90 days of growth (Table 1). 
Table 1 - Percentage of survival, rooting and sprouting of cuttings from post-fire epicormic shoots of erva mate treated with different concentrations of indolebutiric acid (IBA) and grown in different substrates for 90 days.

\begin{tabular}{|c|c|c|c|c|}
\hline \multirow{2}{*}{ Substrates } & \multicolumn{3}{|c|}{ - } & \multirow{2}{*}{ Mean } \\
\hline & \multicolumn{2}{|c|}{$0 \quad 4000$} & 8000 & \\
\hline \multicolumn{5}{|l|}{------------- } \\
\hline Rice husk $^{1}$ & $89.8 \mathrm{Aa}^{2}$ & $89.8 \mathrm{Aa}$ & $89.8 \mathrm{Aa}$ & 89.8 \\
\hline Vermiculite & $89.8 \mathrm{Aa}$ & $89.8 \mathrm{Aa}$ & $84.2 \mathrm{Aa}$ & 87.9 \\
\hline Coarse sand & $80.9 \mathrm{Bb}$ & $78.1 \mathrm{Bb}$ & $87.7 \mathrm{Aa}$ & 82.2 \\
\hline Mean & 86.8 & 85.9 & 87.2 & \\
\hline CV (\%) & 8.2 & & & \\
\hline \multicolumn{5}{|c|}{ 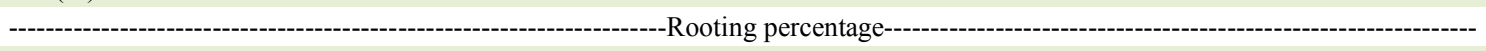 } \\
\hline Rice husk & $13.0 \mathrm{Ba}$ & 21.9 Aab & $25.2 \mathrm{Ab}$ & 20.0 \\
\hline Vermiculite & $23.3 \mathrm{Aa}$ & $29.7 \mathrm{Aa}$ & $21.6 \mathrm{Ab}$ & 24.9 \\
\hline Coarse sand & $15.6 \mathrm{Ba}$ & $17.9 \mathrm{Ba}$ & $44.2 \mathrm{Aa}$ & 25.9 \\
\hline Mean & 17.3 & 23.2 & 30.3 & \\
\hline $\mathrm{CV}(\%)$ & 22.3 & & & \\
\hline \multicolumn{5}{|c|}{ 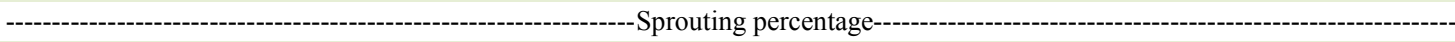 } \\
\hline Rice husk & $85.6 \mathrm{Aa}$ & $80.2 \mathrm{Aa}$ & $68.6 \mathrm{Aa}$ & 78.1 \\
\hline Vermiculite & $89.8 \mathrm{Aa}$ & $88.1 \mathrm{Aa}$ & $69.4 \mathrm{Ba}$ & 82.4 \\
\hline Coarse sand & $89.8 \mathrm{Aa}$ & $82.0 \mathrm{Aa}$ & $49.3 \mathrm{Bb}$ & 73.7 \\
\hline Mean & 88.4 & 83.4 & 62.4 & \\
\hline CV (\%) & 2.2 & & & \\
\hline
\end{tabular}

${ }^{1}$ Carbonized rice husk.

${ }^{2}$ Means followed by the same letter, uppercase in the horizontal and lowercase in the vertical, do not differ by Tukey test (P $\left.\leq 0.05\right)$.

Auxins are commonly employed for rooting of cuttings of tree species, since they provide increased percentage, speed, quality and uniformity of rooting (RISTOW et al., 2010); although, in some cases, they can promote the inhibition of adventitious shoots formation (FERREIRA, 2009). Substrate plays an important role in rooting. In this study, the combination of $8000 \mathrm{mg} \mathrm{L}^{-1}$ of IBA and growth in sand resulted in the highest percentage of rooted cuttings (Table 1). Sand is a substrate with high porosity and low water retention capacity (WADE et al., 2002), enabling greater availability of oxygen at the base of cuttings, with increased cellular activity in the process of root formation (HARTMANN et al., 2011). In addition, sand is more dense compared with carbonized rice husk and vermiculite thus it

Table 2 - Callus percentage, and number and length of roots of cuttings from post-fire epicormic shoots of erva mate treated with different concentrations of indolebutiric acid (IBA) and grown in different substrates for 90 days.

\begin{tabular}{|c|c|c|c|}
\hline Treatments & Number of roots & Length of roots $(\mathrm{cm})$ & Callus percentage \\
\hline \multicolumn{4}{|l|}{ IBA $\left(\mathrm{mg} \mathrm{L}^{-1}\right)$} \\
\hline 0 & $1.1 \mathrm{~b}^{1}$ & $0.90 \mathrm{a}$ & $74.1 \mathrm{a}$ \\
\hline 4000 & $1.3 \mathrm{ab}$ & $0.95 \mathrm{a}$ & $69.5 \mathrm{a}$ \\
\hline 8000 & $1.5 \mathrm{a}$ & $0.87 \mathrm{a}$ & $58.7 \mathrm{~b}$ \\
\hline \multicolumn{4}{|l|}{ Substrate } \\
\hline Carbonized rice husk & $1.2 \mathrm{a}$ & $0.86 \mathrm{a}$ & $66.7 \mathrm{ab}$ \\
\hline Vermiculite & $1.4 \mathrm{a}$ & $0.92 \mathrm{a}$ & $73.9 \mathrm{a}$ \\
\hline Coarse sand & $1.3 \mathrm{a}$ & $0.94 \mathrm{a}$ & $61.5 \mathrm{~b}$ \\
\hline Means & 1.3 & 0.89 & 67.2 \\
\hline CV $(\%)$ & 40.1 & 19.4 & 27.3 \\
\hline
\end{tabular}

${ }^{1}$ Means followed by the same letter do not differ by Tukey test $(\mathrm{P} \leq 0.05)$. 
better supports cuttings, an important feature in vegetative propagation (KÄMPF, 2004).

The different concentrations of IBA did not significantly influence the number of roots formed or length (Table 2). However, callus percentage was affected both by IBA and the type of substrate used. The greatest callus formation occurred in cuttings not treated with IBA, with a decreasing tendency as the concentration of auxin increased to $8000 \mathrm{mg} \mathrm{L}^{-1}$, regardless of the substrate used (Table 2). The use of auxin during adventitious rooting increases the formation of calli, in addition to inducing root formation (PIJUT et al., 2011), which was not observed in this study. There was an antagonistic relationship between the rooting and callus formation, suggesting that these processes compete for assimilates, since the greatest rooting responses generally occurred in treatments with lower callus formation (Tables 1 and 2). A similar result occurred in study on micropropagation of erva mate, where an inverse relation was observed between rooting of apical cuttings and callus formation (HORBACK et al., 2011). With regard to the effect of substrate on callus formation, the fact that there was decreased callus formation when erva mate cuttings were grown in sand indicated the superiority of this substrate, since the absence of calli has been cited as a factor in the formation of adventitious roots (MACHADO et al., 2013).

Application of IBA did not affect the survival of erva mate cuttings grown in carbonized rice husk or vermiculite; however, the use of $8000 \mathrm{mg} \mathrm{L}^{-1} \mathrm{IBA}$ favored survival when grown in sand (Table 1). This result may be related to a greater rooting response for this treatment, because dehydration is one of the main causes of cuttings death, since the absence of roots prevents the absorption of water, while the leaves and shoots continue to lose water by transpiration (LIMA et al., 2011). Even with the variations between the substrates evaluated, there was a high percentage of survival of cuttings of erva mate (Table 1), demonstrating that environmental factors, such as humidity and temperature in the rooting environment were satisfactorily controlled and suitable for the species.
In the experiment with canjerana cuttings, there was a significant interaction between the shoot collection position and concentration of IBA for the number and length of shoots (Table 3 ); however, there was no significant interaction between these factors for survival and rooting percentage and number and length of roots (Table 4). Basal cuttings treated with $6000 \mathrm{mg} \mathrm{L}^{-1}$ of IBA presented a higher number of shoots, differing significantly from other treatments (Table 3), in addition to greater responses of survival and rooting and greater number and length of roots (Table 4).

Use of auxin and the predisposition to differentiate roots are important factors that must be considered in rooting, since tissues obtained from the same plant often have different responses to auxin treatment (PIJUT et al., 2011). Throughout the sprouting process, there may be differences in the content of carbohydrates, amino acids and other substances that serve as energy reserves required for the morphogenetic responses (HARTMANN et al., 2011). This is because, generally, the shoots are thicker at the basal region and become thinner toward the apical end, and the reserve content may change with the collection position. In addition, it was observed that the application of IBA reduced the survival of cuttings of canjerana and, with the exception of medium cuttings, also reduced the length of shoots formed with greater responses in cuttings untreated with IBA (Tables 3 and 4). The application of exogenous auxins favors adventitious rooting, but this response only occurs up to a maximum dose, after which there is an inhibitory effect on root formation (NIENOW et al., 2010).

Change from the juvenile to the mature phase results from the expression of certain genes at specific times in the life cycle of woody species, or in response to environmental or intrinsic signals. The loss of adventitious rooting competence related to maturation is a limiting factor in clonal forestry, since many traits or desirable characteristics are expressed only in adult plants (PIJUT et al., 2011). With the development of production technologies for seedlings

Table 3 - Number and length of cuttings from the basal, median and apical portions of epicormic post-fire shoots of canjerana treated or not with $6000 \mathrm{mg} \mathrm{L}^{-1}$ of indolebutiric acid (IBA) at 90 days of growth.

\begin{tabular}{|c|c|c|c|c|}
\hline & \multicolumn{2}{|c|}{ 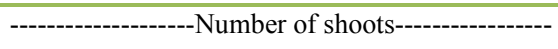 } & \multicolumn{2}{|c|}{----1, } \\
\hline Collection position & $0 \mathrm{mg} \mathrm{L}^{-1}$ & $6000 \mathrm{mg} \mathrm{L}^{-1}$ & $0 \mathrm{mg} \mathrm{L}^{-1}$ & $6000 \mathrm{mg} \mathrm{L}^{-1}$ \\
\hline Basal & $0.3 \mathrm{Ab}^{1}$ & $1.2 \mathrm{Aa}$ & $10.9 \mathrm{Aa}$ & $2.8 \mathrm{Ab}$ \\
\hline Median & $0.0 \mathrm{Aa}$ & $0.3 \mathrm{Ba}$ & $3.6 \mathrm{Ba}$ & $1.6 \mathrm{Aa}$ \\
\hline Apical & $0.0 \mathrm{Aa}$ & $0.2 \mathrm{Ba}$ & $2.5 \mathrm{Ba}$ & $0.8 \mathrm{Ab}$ \\
\hline Mean & 0.1 & 0.5 & 5.6 & 1.7 \\
\hline CV $(\%)$ & \multicolumn{2}{|c|}{27.3} & \multicolumn{2}{|c|}{37.4} \\
\hline
\end{tabular}

${ }^{1}$ Means followed by the same letter, uppercase in the horizontal and lowercase in the vertical, do not differ by Tukey test (P $\leq 0.05$ ). 
Table 4 - Percentage of survival and rooting, number and length of roots of cuttings from the basal, median and apical portions of epicormic post-fire shoots of canjerana treated or not with $6000 \mathrm{mg} \mathrm{L}^{-1}$ of indolebutiric acid (IBA) at 90 days of growth.

\begin{tabular}{|c|c|c|c|c|}
\hline Collection position & Survival percentage & Rooting percentage & Number of roots & Length of roots $(\mathrm{cm})$ \\
\hline Basal & $69.2 \mathrm{a}^{1}$ & $5.1 \mathrm{a}$ & $4.3 \mathrm{a}$ & $4.6 \mathrm{a}$ \\
\hline Median & $37.7 \mathrm{~b}$ & $0.0 \mathrm{~b}$ & $0.0 \mathrm{~b}$ & $0.0 \mathrm{~b}$ \\
\hline Apical & $54.7 \mathrm{ab}$ & $0.0 \mathrm{~b}$ & $0.0 \mathrm{~b}$ & $0.0 \mathrm{~b}$ \\
\hline \multicolumn{5}{|l|}{ IBA $\left(\mathrm{mg} \mathrm{L}^{-1}\right)$} \\
\hline 0 & $62.1 \mathrm{a}$ & $2.5 \mathrm{a}$ & $1.5 \mathrm{a}$ & $2.5 \mathrm{a}$ \\
\hline 6000 & $45.7 \mathrm{~b}$ & $0.9 \mathrm{a}$ & $1.3 \mathrm{a}$ & $0.5 \mathrm{a}$ \\
\hline Mean & 53.8 & 1.7 & 1.4 & 1.5 \\
\hline $\mathrm{CV}(\%)$ & 55.5 & 120.6 & 45.1 & 53.9 \\
\hline
\end{tabular}

${ }^{1}$ Means followed by the same letter do not differ by Tukey test $(\mathrm{P} \leq 0.05)$.

by vegetative propagation, cuttings have been employed primarily for the rescue of genotypes in the field, with subsequent use of the minicutting technique for mass cloning of plants (WADE et al., 2007).

Results of this study indicated that it is possible to rescue erva mate and canjerana adult plants by post-fire shoot cuttings from the tissue differentiation of buds from the stem collar of the tree. Rooting percentage of erva mate cuttings ranged from 13.0 to $44.2 \%$, while for canjerana, rooting ranged from 0 to $5.1 \%$. Plants obtained from these adult plants can be established in clonal garden for production of plantlets by serial minicutting. Serial propagation methods can promote reinvigoration or rejuvenation (WENDLING et al., 2014), which could encourage the mass production of plantlets of erva mate and canjerana.

\section{CONCLUSION}

Cuttings from post-fire epicormic shoots can be used for the rescue of adult plants of erva mate and canjerana. Erva mate cuttings treated with $8000 \mathrm{mg} \mathrm{L}^{-1}$ of IBA and planted in coarse sand have a higher percentage of rooting. Canjerana cuttings obtained from the basal portion of the shoots present greater survival and rooting than those from the median and apical portions.

\section{ACKNOWLEDGEMENTS}

The authors thank Coordenação de Aperfeiçoamento de Pessoal de Nível Superior (CAPES) and Conselho Nacional de Desenvolvimento Científico e Tecnológico (CNPq) for granting research scholarships.

\section{REFERENCES}

BACKES, P.; IRGANG, B. Árvores do Sul: Guia de identificação e interesse ecológico. 2. ed. Porto Alegre: Paisagem do Sul, 2009. 322p.

BITENCOURT, J. et al. Rooting of "erva-mate" (Ilex paraguariensis A. St.-Hill.) cuttings from rejuvenated sprouts. Revista Brasileira de Plantas Medicinais, v.11, n.3, p.277-281, 2009. Available from:
$<$ http://www.scielo.br/pdf/rbpm/v11n3/08.pdf> . Accessed: Ago. 26, 2015. doi: 10.1590/S1516-05722009000300008.

BRASIL. Lei $\mathrm{n}^{\circ} 12.651$, de 25 de maio de 2012. Código Florestal Brasileiro. Available from: $<$ http://www.planalto.gov. br/ccivil_03/_Ato2011-2014/2012/Lei/L12651.htm>. Accessed: Ago. 07, $201 \overline{5}$.

CARVALHO, P. E. R. Espécies florestais brasileiras: recomendações silviculturais, potencialidades e uso da madeira. Colombo: Embrapa Florestas, 2003. v.1, 1039p.

FERRARI, M. P. et al. Propagação vegetativa de espécies florestais. Colombo: Embrapa Florestas, 2004. 22p. Available from: $<$ http://ainfo.cnptia.embrapa.br/digital/bitstream/item/16839/1/ doc94.pdf>. Accessed: Ago. 26, 2015. ISSN: 1679-2599.

FERREIRA, B. G. A. et al. Methodologies of IBA application in the rooting of Sapium glandulatum (Vell.) Pax semi-hardwood cuttings. Revista Brasileira de Plantas Medicinais, v.11, n.2, p.196-201, 2009. Available from: $<$ http://www.scielo.br/scielo.php?script=sci_arttext\&pid $=$ S1516-05722009000200014>. Accessed: Ago. 26, 2015. doi: 10.1590/S1516-05722009000200014.

HACKETT, W. P.; MURRAY, J. R. Maturation and rejuvenation in woody species. In: AHUJA, M.R. (Ed.). Micropropagation of woody plants. Dordrecht: Kluwer Academic Publishers, 1993. p.93-105.

HARTMANN, H. T. et al. Plant propagation: principles and practices. 8. ed. New Jersey: Prentice-Hall, 2011. 915p.

HORBACK, M. A. et al. Micropropagation of holly plantlets obtained from zygotic embryos. Ciência Rural, v.41, n.1, p.113-119, 2011. Available from: <http://www.scielo.br/scielo.php?script=sci pdf\&pid=S0103-84782011000100018\&lng $=$ en\&nrm=iso\&tlng $=$ PT $>$. Accessed: Jul. 27, 2015. doi: 10.1590/S0103-84782011000100018.

KÄMPF, A. N. Evolução e perspectivas do uso de substratos no Brasil. In: BARBOSA, J.; LIMA, D. M. et al. Rooting potential capacity of peach tree cultivars of semi-hardwood and hardwood cuttings treated with iba. Revista Brasileira de Plantas medicinais, v.13, n.4, p.422-438, 2011. Available from: <http:// www.scielo.br/pdf/rbpm/v13n4/a08v13n4.pdf $>$. Accessed: Ago. 18, 2015. doi: 10.1590/S1516-05722011000400008.

LONGHI, R. A. Livro das árvores e arvoretas do Sul. Porto Alegre: L\&PM, 1995. 174p. 
MACHADO, M. P. et al. Application of IBA on in vitro and ex vitro rooting microcutting of Lavandula angustifolia Miller. Journal of Biotechnology and Biodiversity, v.4, n.2, p.153-161, 2013. Available from: <http://revista.uft.edu.br/index.php/JBB/article/ viewFile/458/326>. Accessed: July 24, 2015. ISSN: 2179-4804.

NIENOW, A. A. et al. Rooting of quaresmeira cuttings in two seasons and concentration of indolbutyric acid. Revista Brasileira de Agrociência, v.16, n.1-4, p.139-142, 2010. Available from: $<$ http://periodicos.ufpel.edu.br/ojs2/index.php/CAST/article/ viewArticle/2022>. Accessed: July 24,2015.

PIJUT, P. M.et al. Promotion of adventitious root formation of difficult-to-root hardwood tree species. Horticultural Reviews, v.38, p.213-251, 2011. Available from: <http://onlinelibrary.wiley. com/doi/10.1002/9780470872376.ch6/summary>. Accessed: Ago. 18, 2015. doi: 10.1002/9780470872376.ch6.

REMADE. Mercado de sementes, mudas e viveiros florestais. 2007. Available from: <http://www.remade.com.br/br/ revistadamadeira_materia.php?num $=1182$ \&subject $=$ Mudas $\% 20$ florestais $\&$ title $=$ Mercado $\% 20 \mathrm{de} \% 20$ sementes, $\% 20$ mudas $\% 20$ e\%20viveiros $\% 20$ florestais $\% 3 \mathrm{Cb} \% 3 \mathrm{E} \% 3 \mathrm{C} / \mathrm{b} \% 3 \mathrm{E}>$. Accessed: Ago. 12, 2015.

RISTOW, N. C. et al. Efeito do IBA no enraizamento de microestacas de mirtileiro. Colombo: Embrapa Florestas, 2010. 7p. (Comunicado Técnico, 255). Available from: <https://www. embrapa.br/busca-de-publicacoes/-/publicacao/884919/efeito-doIBA-no-enraizamento-de-microestacas-de-mirtileiro>. Accessed: Ago. 27, 2015.

SANTARELLI, E. G. Produção de mudas de espécies nativas. In: RODRIGUES, R. R.; LEITÃO FILHO, H. F. (Eds.). Matas ciliares: conservação e recuperação. 3. ed. São Paulo: Edusp/ Fapesp, 2004. p.313-318.

WENDLING, I. et al. Production and survival of Ilexparaguariensis minicuttings and ministumps cultivated in semi-hydroponic system. Pesquisa Agropecuária Brasileira, v.42, n.2, p.289-292, 2007. Available from: <http://www.scielo.br/scielo.php?script=sci arttext\&pid=S0100-204X2007000200019>. Accessed: Ago. 27, 2015. doi: 10.1590/S0100-204X2007000200019.

WENDLING, I. et al. Vegetative propagation of adult Ilex paraguariensis trees through epicormic shoots. Acta Scientiarum - Agronomy, v.35, n.1, p.117-125, 2013. Available from: $<$ http://www.scielo.br/scielo.php?pid=S180786212013000100014\&script=sci_arttext $>$. Accessed: Ago. 26, 2015. doi: 10.4025/actasciagron.v35i1.15958.

WENDLING, I. et al. Maturation and related aspects in clonal forestry - part II: reinvigoration, rejuvenation and juvenility maintenance. New Forests, v.45, p.473-486, 2014b. Available from: $<$ http://link.springer. com/article/10.1007\%2Fs11056-014-9415-y\#page-1>. Accessed: July 20, 2015. doi: 10.1007/s11056-014-9415-y. 